Article

\title{
Simultaneous Control of Staphylococcus aureus and Bacillus cereus Using a Hybrid Endolysin LysB4EAD-LysSA11
}

\author{
Bokyung Son ${ }^{1,2}$, Minsuk Kong ${ }^{3}$, Yoyeon Cha ${ }^{1,2}$, Jaewoo Bai ${ }^{4}$ and Sangryeol Ryu ${ }^{1,2,5,6, *(D)}$ \\ 1 Department of Food and Animal Biotechnology, Seoul National University, Seoul 08826, Korea; \\ sonbk0722@gmail.com (B.S.); dianacha2006@naver.com (Y.C.) \\ 2 Department of Agricultural Biotechnology, Seoul National University, Seoul 08826, Korea \\ 3 Department of Food Science and Technology, Seoul National University of Science and Technology, \\ Seoul 01811, Korea; kongmin1@seoultech.ac.kr \\ 4 Division of Applied Food System, Food Science \& Technology, Seoul Women's University, Seoul 01797, \\ Korea; jwbai@swu.ac.kr \\ 5 Research Institute of Agriculture and Life Sciences, Seoul National University, Seoul 08826, Korea \\ 6 Center for Food and Bioconvergence, Seoul National University, Seoul 08826, Korea \\ * Correspondence: sangryu@snu.ac.kr; Tel.: +82-2-880-4863; Fax: +82-2-873-5095
}

Received: 24 November 2020; Accepted: 11 December 2020; Published: 14 December 2020

\begin{abstract}
Bacteriophage endolysins have attracted attention as promising alternatives to antibiotics, and their modular structure facilitates endolysin engineering to develop novel endolysins with enhanced versatility. Here, we constructed hybrid proteins consisting of two different endolysins for simultaneous control of two critical foodborne pathogens, Staphylococcus aureus and Bacillus cereus. The full-length or enzymatically active domain (EAD) of LysB4, an endolysin from the B. cereus-infecting phage B4, was fused to LysSA11, an endolysin of the S. aureus-infecting phage SA11, via a helical linker in both orientations. The hybrid proteins maintained the lytic activity of their parental endolysins against both S. aureus and B. cereus, but they showed an extended antimicrobial spectrum. Among them, the EAD of LysB4 fused with LysSA11 (LysB4EAD-LyaSA11) showed significantly increased thermal stability compared to its parental endolysins. LysB4EAD-LysSA11 exhibited high lytic activity at $\mathrm{pH}$ 8.0-9.0 against $S$. aureus and at $\mathrm{pH} 5.0-10.0$ against $B$. cereus, but the lytic activity of the protein decreased in the presence of $\mathrm{NaCl}$. In boiled rice, treatment with $3.0 \mu \mathrm{M}$ of LysB4EAD-LysSA11 reduced the number of S. aureus and B. cereus to undetectable levels within $2 \mathrm{~h}$ and also showed superior antimicrobial activity to LyB4EAD and LysSA11 in combination. These results suggest that LysB4EAD-LysSA11 could be a potent antimicrobial agent for simultaneous control of S. aureus and B. cereus.
\end{abstract}

Keywords: endolysin; protein engineering; hybrid protein; biocontrol agent

\section{Introduction}

Food poisoning outbreaks caused by bacterial pathogens are a major concern worldwide. In the United States, approximately 9.4 million foodborne illnesses with about 56,000 hospitalizations and 1300 deaths caused by major foodborne pathogens are reported every year [1]. In particular, 300,000 cases are caused by Bacillus cereus or Staphylococcus aureus, which are considered important bacteria in terms of infection frequency and seriousness of the disease [1]. A previous study demonstrated that $B$. cereus and S. aureus frequently contaminate foods such as milk or rice-based foods, and they can cause outbreaks in similar food products [2]. Moreover, the symptoms of food poisoning caused by $B$. cereus and S. aureus highly resemble other foodborne infections [3]. Due to these symptomatic 
similarities, B. cereus food poisonings are occasionally misdiagnosed as S. aureus intoxication [4]. Thus, simultaneous control of both $S$. aureus and B. cereus would be highly meaningful.

Since antibiotic-resistant bacteria have increased, phage endolysins have attracted attention as a promising alternative to antibacterial agents $[5,6]$. Most endolysins from the phages infecting Gram-positive bacteria have a modular structure, in which one or several enzymatically active domains (EAD) and a cell wall binding domain (CBD) are functionally separated by a short linker [7-9]. In the case of staphylococcal phage endolysins, they typically consist of a CHAP domain and an amidase domain as an EAD and a CBD [10]. The phage endolysins' modular structure facilitates endolysin engineering to alter lytic activity, target specificity, protein solubility, and other properties [11]. A variety of protein engineering strategies have been attempted to optimize endolysins for specific applications [7,12]. Donovan et al. [13] reported that the full length and C-terminally truncated phage endolysin from Streptococcus agalactiae bacteriophage B30 was fused to the lysostaphin. These proteins degraded both streptococcal and staphylococcal cells, and their lytic activities were tested in milk. This group also created hybrid proteins with the endopeptidase of streptococcal phage $\lambda S A 2$ endolysin with the Staphylococcus-specific CBDs of either the endolysin LysK or lysostaphin. The altered CBDs conferred lytic activity against staphylococci and streptococci on the streptococcal enzyme [14].

Here, we created new hybrid endolysins targeting multiple pathogenic bacteria with two phage endolysins. Constructed hybrid endolysins acted independently and maintained lytic activity of their parental endolysins against both S. aureus, B. cereus and Listeria monocytogenes, indicating a successfully extended antimicrobial spectrum. In particular, LysB4EAD-LysSA11 showed higher thermal stability than their parental endolysins and potent antimicrobial activity against $S$. aureus and B. cereus in boiled rice. This hybrid endolysin would be a promising antimicrobial agent for the simultaneous control of S. aureus and B. cereus. Moreover, this approach will provide an opportunity to design multifunctional and highly specific antimicrobials, thereby helping reduce the incidence of multidrug-resistant bacteria.

\section{Results and Discussion}

\subsection{Construction and Expression of the Hybrid Proteins}

LysSA11 and LysB4 were selected for the construction of hybrid proteins with the goal of controlling S. aureus and B. cereus simultaneously. LysSA11 is an endolysin derived from the virulent S. aureus phage SA11 [15]. While most S. aureus endolysins are composed of three domains, LysSA11 is composed of two functional domains: a CHAP domain at its $\mathrm{N}$-terminal region and a CBD at its C-terminal region, making it more suitable to be fused with other endolysins. More importantly, it has strong lytic activity against $S$. aureus strains. LysB4 is a B. cereus phage endolysin, which exhibited the enzymatic activity of an L-alanoly-D-glutamate endopeptidase on peptidoglycans [16]. LysB4 showed strong lytic activity against a broad range of pathogenic bacteria, including Bacillus species and Listeria monocytogenes. Using these two endolysins, we generated various types of hybrid endolysins. First, two full-length endolysins were connected by a helical linker, either LysSA11 at the N-terminal (LysSA11-LysB4) or LysB4 at the N-terminal (LysB4-LysSA11) (Figure 1A). Then, we created other hybrid endolysins with truncated endolysins with the potential to optimize their antimicrobial activity.

A previous study reported that the C-terminal domain of the endolysin PlyL encoded in the B. anthracis genome could inhibit the enzymatic activity of its EAD in the absence of the cognate target $[17,18]$. In this regard, we have constructed LysSA11EAD (1-159 amino acids) and LysB4EAD (1-176 amino acids), which are C-terminally truncated versions of LysSA11 and LysB4, respectively (Figure S1). The turbidity reduction assay revealed that the lytic activity of LysSA11EAD significantly decreased compared to that of full-length LysSA11 against $S$. aureus with the same molar concentration $(0.3 \mu \mathrm{M})$. Even a higher amount of LysSA11EAD $(1.0 \mu \mathrm{M})$ did not show comparable staphylolytic activity to $0.3 \mu \mathrm{M}$ of LysSA11, suggesting that CBD is essential for the lytic activity of LysSA11. Similarly, LysPBC1 endolysin from $B$. cereus-infecting phage $\mathrm{PBC} 1$ showed stronger lytic activity against $B$. cereus than LysPBC1EAD [19]. On the other hand, LysB4EAD exhibited almost equal lytic 
activity to that of LysB4, indicating LysB4CBD may not be essential to the enzymatic activity of LysB4. We then constructed two more hybrid endolysins by connecting either LysSA11 at the N-terminal (LysSA11-LysB4EAD) or LysB4EAD at the N-terminal (LysB4EAD-LysSA11) (Figure 1A) via a helical linker. All constructed proteins were overexpressed in soluble form in E. coli, and purified proteins were visualized as a single band with the expected molecular mass on SDS-PAGE gel (Figure 1B).

A

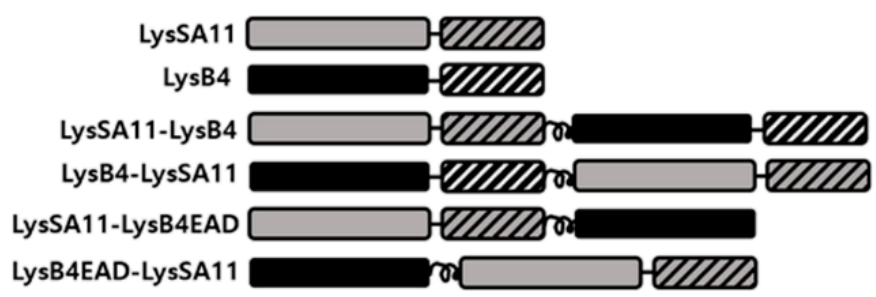

B

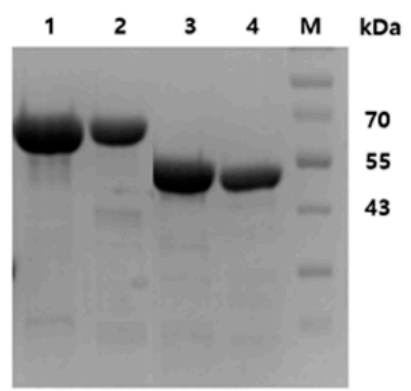

Figure 1. The modular structure of hybrid proteins and their lytic activity. (A) Schematic representation of LysSA11, LysB4, LysSA11-LysB4, LysB4-LysSA11, LysSA11-LysB4EAD, and LysB4EAD-LysSA11. LysSA11EAD: gray box; LysSA11CBD, gray diagonal stripe; LysB4EAD, black box; LysB4CBD, white diagonal stripe. (B) Purified LysSA11-LysB4, LysB4-LysSA11, LysSA11-LysB4EAD, and LysB4EAD-LysSA11 were loaded on an SDS-PAGE gel. Lane 1, purified LysSA11-LysB4 fraction; lane 2, purified LysB4-LysSA11 fraction; lane 3, purified LysSA11-LysB4EAD; lane 4, purified LysB4EAD-LysSA11 fraction; lane M, molecular weight marker.

\subsection{Lytic Activity of the Hybrid Endolysins}

The relative lytic activity of the hybrid endolysins was determined by measuring the decrease in optical density at $600 \mathrm{~nm}\left(\mathrm{OD}_{600}\right)$ of S. aureus (Figure $\left.2 \mathrm{~A}\right)$ and B. cereus (Figure 2B). The monitored OD 600 values of $S$. aureus and B. cereus are presented in Table S1 and Table S2, respectively. LysSA11-LysB4, LysB4-LysSA11, LysSA11-LysB4EAD, and LysB4EAD-LysSA11 were as active as their parental endolysins, indicating that constructed hybrid proteins acted independently and maintained the lytic activity of their parental endolysins. Interestingly, the staphylolytic activity of LysSA11 appeared to be affected by adding LysB4 or LysB4EAD to its N-terminus, resulting in a decrease in the lysis rate of LysB4-LysSA11and LysB4EAD-LysSA11. The results indicate that the orientation of the proteins to be fused can affect the lysis rate of hybrid proteins.

A

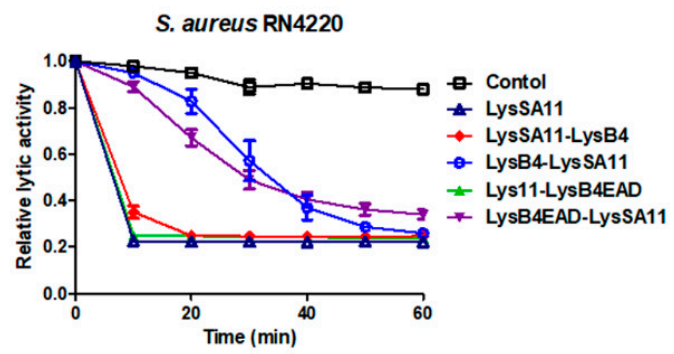

B

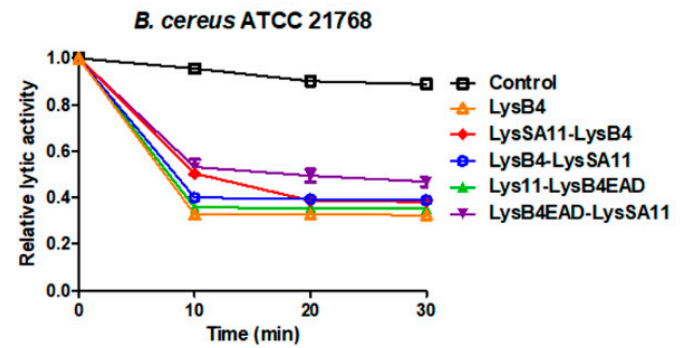

Figure 2. Lytic activity of the hybrid proteins. Relative lytic activity of LysSA11-LysB4, LysB4-LysSA11, LysSA11-LysB4EAD, and LysB4EAD-LysSA11 against (A) S. aureus RN4220 and (B) B. cereus ATCC 21768 was measured by monitoring a decrease in turbidity compared to their parental endolysins.

\subsection{The Antibacterial Spectrum of the Hybrid Proteins}

The antimicrobial activity of the hybrid proteins was evaluated against Gram-positive bacteria (Table 1). As previously reported, LysSA11 exhibited lytic activity against all staphylococcal strains 
tested and had no effect on B. cereus and other Gram-positive bacteria. Likewise, LysB4 was active against $B$. cereus, $B$. subtilis, and $L$. monocytogens, but not against staphylococcal strains. On the other hand, LysSA11-LysB4, LysB4-LysSA11, LysSA11-LysB4EAD, and LysB4EAD-LysSA11 appeared to have the same antibacterial spectrum, killing not only staphylococcal strains but also B. cereus, B. subtilis, and L. monocytogens. These results demonstrate that the antimicrobial spectrum of the constructed hybrid proteins was extended compared to their parental endolysins, and the hybrid proteins maintained the specificities of their parental endolysins.

Table 1. The antibacterial spectra of the hybrid proteins.

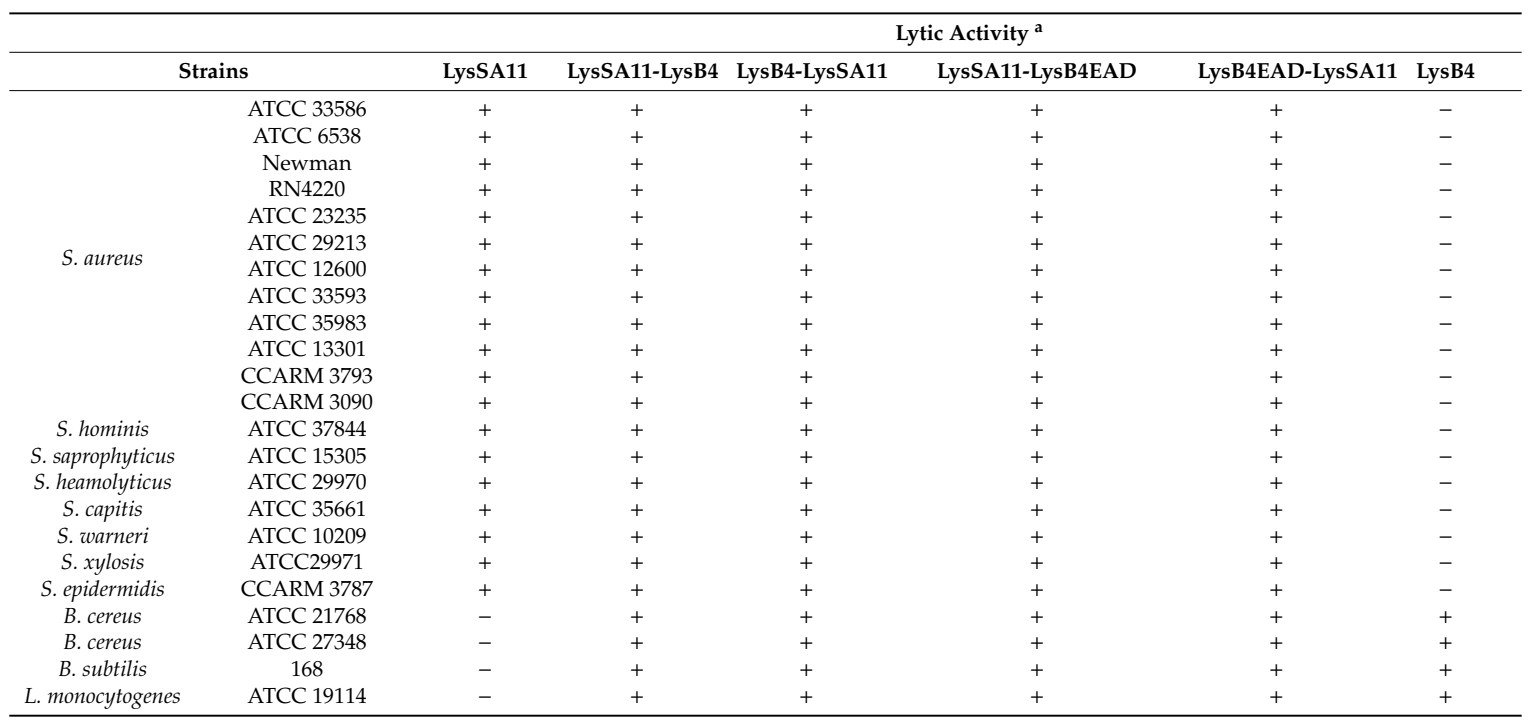

a +, Lysis; -, No lysis.

\subsection{Thermal Stability Determination}

The thermal stability of the endolysins is an essential factor in the development of biocontrol agents. In general, most phage endolysins are not stable to heat and lose their activity above $50-60{ }^{\circ} \mathrm{C}$ [20]. The thermal stability assay showed that the lytic activity of LysSA11 significantly decreased after $30 \mathrm{~min}$ incubation at $45^{\circ} \mathrm{C}$ against $S$. aureus. However, all hybrid proteins constructed in this study showed strong lytic activity at $45^{\circ} \mathrm{C}$ and had a low activity even at $55^{\circ} \mathrm{C}$, demonstrating that the hybrid proteins had enhanced thermal stability compared to their parental endolysin, LysSA11 (Figure 3A). Meanwhile, the hybrid proteins showed a different thermal stability pattern against $B$. cereus from that against S. aureus. LysSA11-LysB4 and LysSA11-LysB4EAD retained only 20\% of the lytic activity of LysB4 after heating at $55^{\circ} \mathrm{C}$. However, LysB4-LysSA11 and LysB4EAD-LysSA11 had similar thermal stabilities to LysB4, which was relatively stable at most of the temperatures tested. They also exhibited even higher lytic activity than LysB4 at $65^{\circ} \mathrm{C}$ (Figure 3B). Consistent with our results, previous studies have found several hybrid proteins with improved thermal stability compared to their parental proteins, demonstrating that improvements are likely due to the $\alpha$-helical linker [21-23]. The rigid structure of the helical linker provides enough space or specific physical adaptation between parental enzymes, enhancing the bifunctional activity of the hybrid protein. These results led us to assume that the thermal stability of hybrid endolysin might be affected by the inserted linker and the orientation of the parental endolysins to be fused. We selected LysB4EAD-LysSA11, which showed the highest lytic activity against both $S$. aureus and B. cereus at a high temperature, for further study. 
A

S. aureus RN4220

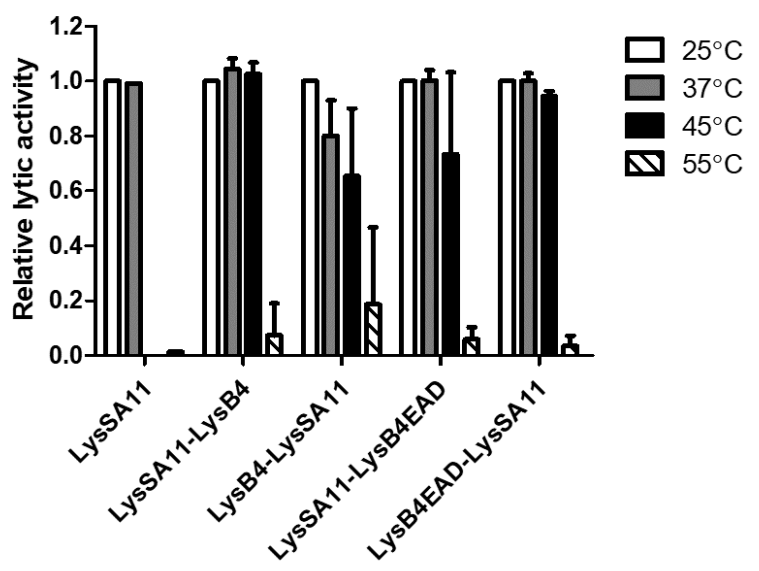

B

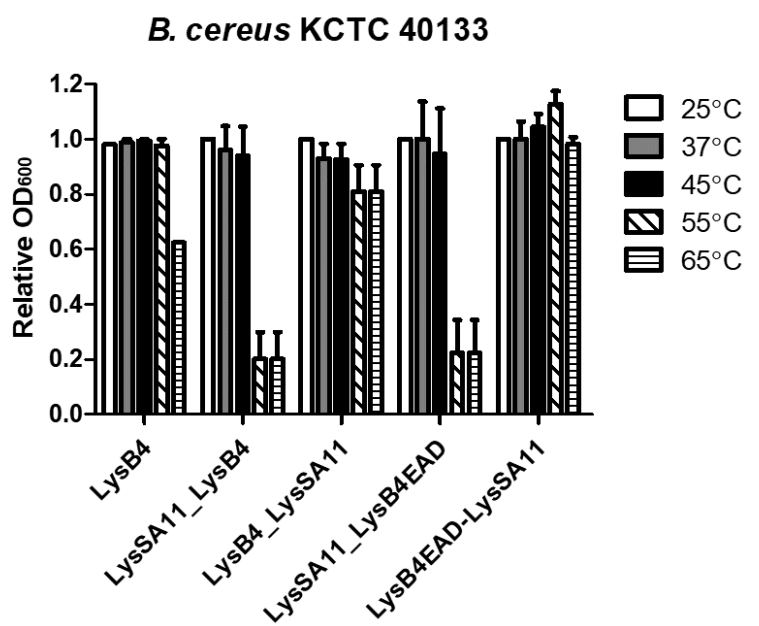

Figure 3. The thermal stability of the hybrid proteins. Equimolar concentrations ( $300 \mathrm{nM}$ ) of LysSA11, LysB4, LysSA11-LysB4, LysB4-LysSA11, LysSA11-LysB4EAD, and LysB4EAD-LysSA11 were incubated in reaction buffer at different temperatures for $30 \mathrm{~min}$. Relative lytic activities against (A) S. aureus RN4220 and (B) B. cereus ATCC 21768 were calculated using the activity of the enzyme stored at $25^{\circ} \mathrm{C}$, which showed the maximal activity.

\subsection{Effect of $\mathrm{pH}$ and $\mathrm{NaCl}$ on the Lytic Activity of LysB4EAD-LysSA11}

First, we evaluated the lytic activity of the hybrid proteins at different $\mathrm{pH}$ values. LysB4EAD-LysSA11 had more than $80 \%$ of its maximal activity at $\mathrm{pH} 8.0-9.0$ against S. aureus (Figure 4A). In contrast, it was relatively stable under a broad range of $\mathrm{pH}$ between $\mathrm{pH}$ 5.4-9.0 against B. cereus (Figure $4 \mathrm{~B}$ ), showing more than $60 \%$ residual activity even at $\mathrm{pH} 5.4$. These results could be attributed to the different behavior of $S$. aureus and B. cereus at various $\mathrm{pH}$ conditions [24]. S. aureus contains teichoic acids in the peptidoglycan (PG) layer, and the teichoic acids have ribitol phosphates, which make the $S$. aureus PG negatively charged. However, the positive charge from the free amino groups of D-Ala reduces the charge. According to a previous study, the S. aureus PG becomes neutral or even has a slightly positive charge at a low $\mathrm{pH}$ and is much more negatively charged at a high $\mathrm{pH}$ [24]. Therefore, in acidic conditions, LysB4EAD-LysSA11 ( $\mathrm{pI}=9.20)$ was more likely to be positively charged, and thus the lytic activity might decrease due to repelling the proteins and the S. aureus PG. Meanwhile, B. cereus contains uncharged polysaccharide branches rather than teichoic acid [25]. The presence of 
diaminopimelic acid and glutamic acid makes the B. cereus cell wall more negatively charged, allowing LysB4EAD-LysSA11 to be more active under a broad range of $\mathrm{pH}$ values compared to $S$. aureus.

A

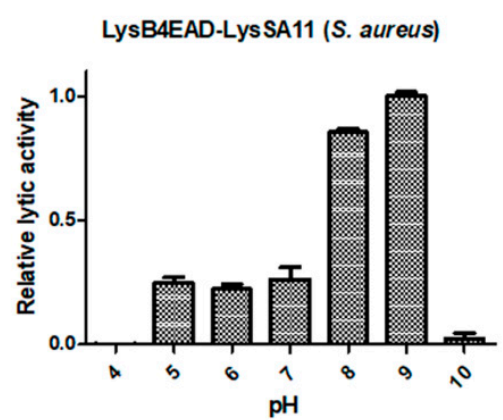

C

LySB4EAD-LysSA11 (S. aureus)

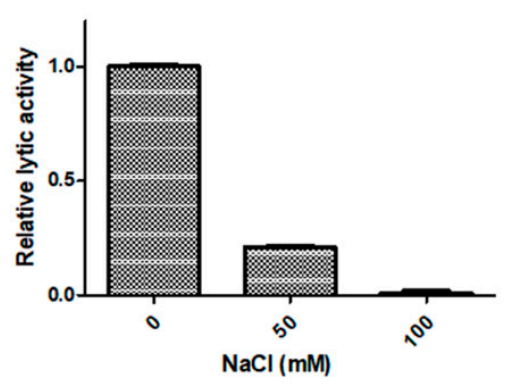

B

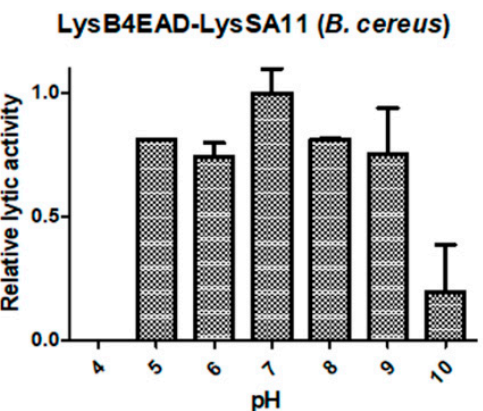

D

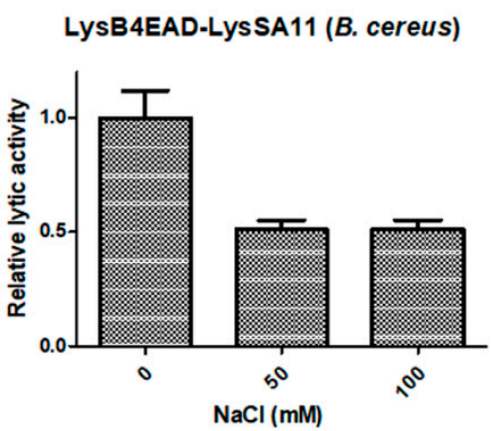

Figure 4. The effect of $\mathrm{pH}$ and $\mathrm{NaCl}$ on the lytic activity of LysB4EAD-LysSA11. The lytic activity of LysB4EAD-LysSA11 against (A) S. aureus RN4220 and (B) B. cereus ATCC 21768 was evaluated under different $\mathrm{pH}$ conditions. The lytic activity of LysB4EAD-LysSA11 against (C) S. aureus RN4220 and (D) B. cereus ATCC 21768 was evaluated at different $\mathrm{NaCl}$ concentrations.

Next, the influence of $\mathrm{NaCl}$ on the lytic activity of LysB4EAD-LysSA11 was determined. The lytic activity against $S$. aureus and B. cereus decreased more than $50 \%$ in the presence of 50 $\mathrm{mM} \mathrm{NaCl}$ (Figure 4C,D), which must be improved for the development of LysB4EAD-LysSA11 as a biocontrol agent.

\subsection{Antimicrobial Activity of LysB4EAD-LysSA11 in Boiled Rice}

To confirm the potential of LysB4EAD-LysSA11 as a biocontrol agent, it was applied to boiled rice samples. The boiled rice was artificially contaminated with $S$. aureus and B. cereus to mimic the natural environment for bacterial contamination of foods. Rice-based foods are frequently implicated as a source of S. aureus and B. cereus food poisoning [26-28]. LysB4EAD-LysSA11 showed lytic activity in a limited salt concentration range, indicating that boiled rice is suitable for the activity test of LysB4EAD-LysSA11. The treatment of LysSA11 and LysB4EAD in combination $(3.0 \mu \mathrm{M}$ each) reduced viable $S$. aureus cells to undetectable levels within $1 \mathrm{~h}$ (Figure $5 \mathrm{~A}$ ) and B. cereus cells by $1 \log \mathrm{CFU} / \mathrm{mL}$ within $3 \mathrm{~h}$ (Figure 5B). These results demonstrate that the antimicrobial activity of LysB4EAD against B. cereus is less effective in food than in reaction buffer. A previous study explained that complex matrixes such as food products might reduce the activity of endolysins by restricting access to the target bacteria [29]. In this regard, it is conceivable that LysB4 may require CBD to facilitate access to target bacteria in boiled rice. Meanwhile, $3.0 \mu \mathrm{M}$ of LysB4EAD-LysSA11 eliminated all S. aureus and B. cereus cells from boiled rice within $2 \mathrm{~h}$ and $1 \mathrm{~h}$, respectively, indicating that the hybrid protein has strong antimicrobial activity against $S$. aureus and B. cereus (Figure 5C,D). In boiled rice, LysB4EAD-LysSA11 showed enhanced antimicrobial activity compared to LysB4EAD itself against $B$. cereus, indicating that 
LysSA11 may serve to help LysB4EAD exert its enzymatic activity. It has been reported that LysSA11 does not have a cell wall binding ability against $B$. cereus since $S$. aureus and B. cereus have different PG structures [15]. However, LysSA11 displayed a positive net charge under experimental conditions ( $\mathrm{pI}$ value of LysSA11, 9.2), suggesting that it can help the fusion partner (LysB4EAD) break down the cell wall through weak interactions with negatively charged target bacteria. We also observed that LysB4EAD-LysSA11 had increased antimicrobial activity compared to a mixture of LysSA11 and LysB4, which were used for generating a hybrid endolysin (Figure S2). These results indicate the evident advantages of the protein hybrid, such as an expansion of the antimicrobial spectrum and activity when it was applied to food.

A

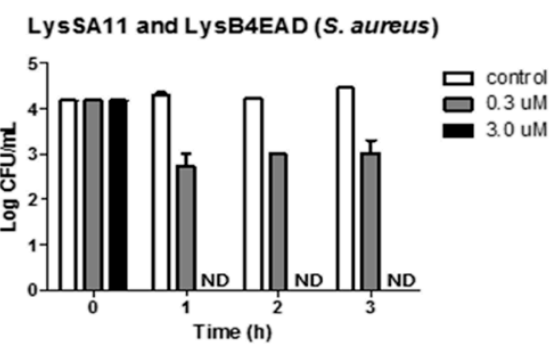

C

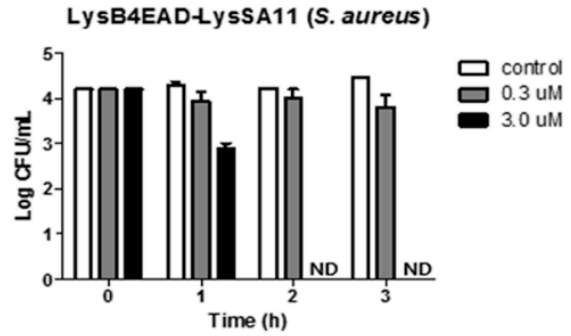

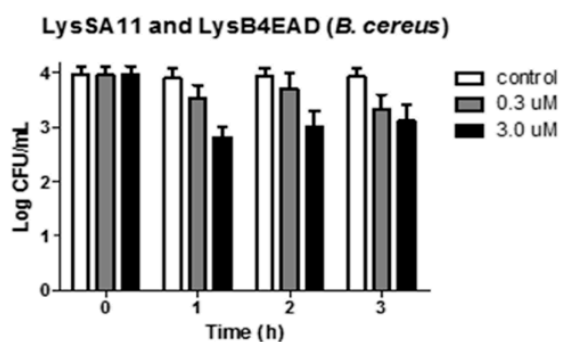

D

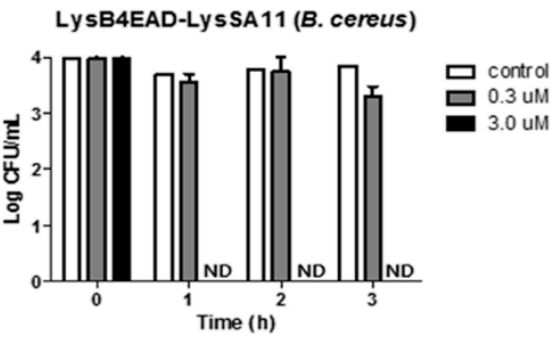

Figure 5. The antimicrobial activity of LysSA11 and LysB4EAD in combination and the hybrid endolysin LysB4EAD-LysSA11 in boiled rice contaminated simultaneously with S. aureus and B. cereus. The numbers of S. aureus RN4220 (A,C) and B. cereus ATCC 21768 (B,D) cells in boiled rice were counted after treatment with different concentrations $(0.3 \mu \mathrm{M}$ and $3.0 \mu \mathrm{M})$ of LysSA11 and LysB4EAD in combination (A,B), and LysB4EAD-LysSA11 (C,D). ND, not detected.

\section{Materials and Methods}

\subsection{Bacterial Strains and Growth Conditions}

All Staphylococcus strains were grown in tryptic soy broth (TSB; Difco, Detroit, MI, USA) at $37^{\circ} \mathrm{C}$. All Bacillus, Listeria, Streptococcus strains were grown in brain heart infusion (BHI; Difco) broth at $37^{\circ} \mathrm{C}$. Gram-negative bacteria were grown in LB broth at $37^{\circ} \mathrm{C}$. All tested bacteria were grown under aerobic conditions. Escherichia coli DH5 $\alpha$ and BL21 (DE3) star strains were used in the cloning and expression of proteins, respectively. Baird-Parker agar plates with egg yolk tellurite (BPA; Difco) were used for selective enumeration of $S$. aureus and a Bacillus cereus selective agar plate with egg yolk emulsion and polymyxin B supplement (Oxoid) was used for selective enumeration of B. cereus.

\subsection{Construction of Recombinant Proteins}

LysSA11, LysB4, and LysB4EAD were connected by a helical linker (EAAAK) ${ }_{4}$ according to a previous study [30]. Hybrid proteins were constructed by an overlapping extension PCR described previously [31]. Plasmids and primers used in this study are listed in Table 2. The lysSA11 gene was amplified from pET29b-LysSA11 [15], while lysB4 and lysB4EAD genes were amplified from pET15b-LysB4 [16]. The two overlapping PCR fragments containing a helical linker were used for the 
second PCR step to generate the lysB4-lysSA11 or lysB4EAD-lysSA11 in both orientations. The resulting PCR products were inserted between the BamHI/SalI restriction enzyme sites of pET28a and all constructed plasmids were confirmed by DNA sequencing at Macrogen Inc. (Seoul, Korea). The cloned plasmids were transformed into E. coli BL21 (DE3).

Table 2. Plasmids and primers used in this study.

\begin{tabular}{|c|c|c|}
\hline \multicolumn{3}{|c|}{ Plasmids } \\
\hline & Descriptions & References \\
\hline pET28a & $\mathrm{Kan}^{\mathrm{r}}$, T7 promoter, His-tagged expression vector & Novagen, Wisconsin, SA \\
\hline pET15b-LysB4 & pE15b with LSA12CBD & [16] \\
\hline pET29b-LysSA11 & pET29a with LSA97CBD & [15] \\
\hline \multicolumn{3}{|c|}{ Primers $\left(5^{\prime} \rightarrow 3^{\prime}\right)$} \\
\hline \multicolumn{3}{|c|}{ Sequences } \\
\hline B4EAD_HL_overl_R & TTT TGC CGC AGC TTC TTT TGC CGC AGC TTC TTT TGC CGC AGC TTC & \\
\hline SA11EAD_Sal1_R & TTT GTC GAC TTG TAC CTC GTC TTT GAA ATT AGG & \\
\hline & TTT TGC CGC AGC TTC TTT TGC CGC AGC TTC TTT TGC CGC AGC TTC & \\
\hline SAIIEAD_HL_overI_K & TTT TGC CGC AGC TTC TTG TAC CTC GTC TTT GAA ATT AGG & \\
\hline B4EAD_Sal1_R & TTT GTC GAC TCC ACC TGT AGA GCC ACC TCC & \\
\hline BamH1_B4_F & AAA GGA TCC ATG GCA ATG GCA TTA CAA ACT T & \\
\hline B4_HL_overl_R & TTT TGC CGC AGC TTC TTT TGC CGC AGC TTC TTT TGC CGC AGC TTC & \\
\hline & TTT TGC CGC AGC TTC TTT GAA CGT ACC CCA GTA GTT C & \\
\hline SA11_Sal1_R & TTT GTC GAC TTT CCA GTT AAT ACG ACC CCA A & \\
\hline BamH1_SA11_F & AAA GGA TCC ATG AAA GCA TCG ATG ACT AGA A & \\
\hline SA11_HL_overl_R & TTT TGC CGC AGC TTC TTT TGC CGC AGC TTC TTT TGC CGC AGC TTC & \\
\hline & TTT TGC CGC AGC TTC TTT CCA GTT AAT ACG ACC CCA A & \\
\hline HL_B4_overl_F & $\begin{array}{l}\text { GAA GCT GCG GCA AAA GAA GCT GCG GCA AAA GAA GCT GCG GCA } \\
\text { AAA GAA GCT GCG GCA AAA ATG GCA ATG GCA TTA CAA ACT TT }\end{array}$ & \\
\hline B4_Sal1_R & TTT GTC GAC TTT GAA CGT ACC CCA GTA GTT C & \\
\hline
\end{tabular}

\subsection{Protein Expression and Purification}

The protein expression was induced with $0.5 \mathrm{mM}$ IPTG (isopropyl- $\beta$-D-thiogalactopyranoside) at $\mathrm{OD}_{600}=0.7$, followed by additional incubation for $20 \mathrm{~h}$ at $18{ }^{\circ} \mathrm{C}$. Bacterial cells were suspended in lysis buffer (50 mM Tris- $\mathrm{HCl}, 300 \mathrm{mM}$ sodium chloride, and 30\% glycerol at $\mathrm{pH} 8.0$ ) and were disrupted by sonication at a duty cycle of $25 \%$ and an output control of 5 (BRANSON ULTRASONICS, Danury, CT, USA). After centrifugation $(20,000 \times g, 30 \mathrm{~min})$, the supernatant passed through a Ni-nitrilotriacetic acid (NTA) superflow column (Qiagen $\mathrm{GmbH}$, Germany), and purification of the recombinant proteins was performed according to the manufacturer's instructions. The purified protein was stored at $-80{ }^{\circ} \mathrm{C}$ until use after the buffer was changed to the storage buffer $(50 \mathrm{mM}$ Tris- $\mathrm{HCl}, 300 \mathrm{mM} \mathrm{NaCl}$, and $30 \%$ glycerol; pH 8.0) using PD Miditrap G-25 (GE healthcare, Amersham, Buck, UK).

\subsection{Lytic Activity Assay}

The lysis of the hybrid endolysins was assessed by a turbidity reduction assay (Son et al., 2012). Bacterial cells grown in the exponential phase were re-suspended with the reaction buffer (20 mM Tris- $\mathrm{HCl}, \mathrm{pH}$ 8.0). Then, purified proteins were added to the cell suspension at a final concentration of $0.3 \mu \mathrm{M}$, and the $\mathrm{OD}_{600}$ reduction of cells was measured over time at room temperature using a SpectraMax i3 multimode microplate reader at $600 \mathrm{~nm}$. The relative lytic activity was calculated after 60 min as follows: ( $\triangle$ OD600 test (endolysin added) - $\Delta$ OD600 control (buffer only))/initial OD600.

The antimicrobial spectrum was tested by plate lysis assay as previously described [15]. Briefly, $10 \mu \mathrm{L}$ of diluted endolysin $(10 \mathrm{pmol})$ was spotted onto a freshly prepared bacterial lawn on agar plates. Spotted plates were air-dried in a laminar flow hood for $15 \mathrm{~min}$ and incubated overnight at $37^{\circ} \mathrm{C}$.

\subsection{Effect of $\mathrm{pH}$ and Temperature on the Endolysin Activity}

For the temperature stability assay of the hybrid proteins, lytic activity was measured at $25^{\circ} \mathrm{C}$ for $60 \mathrm{~min}$ after the enzyme was incubated at various temperatures $\left(4-65^{\circ} \mathrm{C}\right)$ for $30 \mathrm{~min}$. To study the effect of temperature on the enzymatic activity of the fusion proteins, $0.3 \mu \mathrm{M}$ of each protein was 
added into a target cell suspension, and the mixture was incubated at different temperatures $\left(4-65^{\circ} \mathrm{C}\right)$ for $60 \mathrm{~min}$ for the reaction. To test the effect of $\mathrm{pH}$ on the lytic activity of the hybrid proteins, 0.3 $\mu \mathrm{M}$ of each protein were added to the $S$. aureus RN4220 and B. cereus ATCC 21768 cells suspended in the following buffers: $50 \mathrm{mM}$ sodium acetate ( $\mathrm{pH} 4.5$ and 5.4), $50 \mathrm{mM}$ Tris- $\mathrm{HCl}$ (pH 6.5-8.0), $50 \mathrm{mM}$ glycine ( $\mathrm{pH}$ 9.0), and $50 \mathrm{mM}$ N-cyclohexyl-3-aminopropanesulfonic acid (pH 10.0).

\subsection{Antimicrobial Activity in Food Samples}

The hybrid proteins were evaluated for their lytic activity in boiled rice because rice is frequently a source of $S$. aureus and B. cereus food poisoning [26,27]. The samples were prepared as described previously [19]. Briefly, sterilized instant rice was purchased at a local market and was heated using a microwave. The resulting cooked rice $(10 \mathrm{~g})$ was homogenized in $40 \mathrm{~mL}$ distilled water. Then, the slurry samples were artificially contaminated with MRSA CCARM $3089\left(10^{5} \mathrm{CFU} / \mathrm{mL}\right)$ and B. cereus ATCC $21768\left(10^{4} \mathrm{CFU} / \mathrm{mL}\right)$, followed by pre-incubating at $25{ }^{\circ} \mathrm{C}$ for $1 \mathrm{~h}$ to allow them to adapt to boiled rice samples. Enzymes were added to each sample at concentrations of $0,0.3$ and $3 \mu \mathrm{M}$, and the mixtures further were incubated at $25^{\circ} \mathrm{C}$ for $4 \mathrm{~h}$. Viable bacterial cells (CFU/mL) were counted every $1 \mathrm{~h}$ by plating each sample on a BPA for $S$. aureus and B. cereus selective agar plates for B. cereus.

\section{Conclusions}

We proposed an endolysin engineering strategy to control S. aureus and B. cereus simultaneously by constructing hybrid proteins consisting of LysSA11 and LysB4. The hybrid proteins showed an extended antimicrobial spectrum, maintaining the lytic activity of their parental endolysins against both $S$. aureus and B. cereus. Among the hybrid proteins tested, LysB4EAD-LysSA11 showed the most improved thermal stability compared to its parental endolysins, representing a great advantage of the protein hybrid. We also observed that LysB4EAD-LysSA11 had a more effective antimicrobial activity against $S$. aureus and B. cereus in a food matrix compared to mixture of two parental endolysins. The overall characteristics of LysB4EAD-LysSA11 are summarized in Table 3. These results suggest that LysB4EAD-LysSA11 could be a potent antimicrobial agent for simultaneous control of multiple pathogenic bacteria and this study will be helpful in designing highly specific but multifunctional antimicrobials.

Table 3. Results summary.

\begin{tabular}{ccc}
\hline Figure \# & Target Bacteria & Observation \\
\hline Figure 3A & S. aureus & LysB4EAD-LysSA11 is stable up to $45^{\circ} \mathrm{C}$ while LysSA11 is stable up to $37^{\circ} \mathrm{C}$. \\
Figure 3B & B. cereus & LysB4EAD-LysSA11 is stable up to $65^{\circ} \mathrm{C}$ while LysB4 is stable up to $55^{\circ} \mathrm{C}$. \\
Figure 4A & S. aureus & LysB4EAD-LysSA11 is highly active at $\mathrm{pH} 8.0-9.0$. \\
Figure 4B & B. cereus & LysB4EAD-LysSA11 is highly active at $\mathrm{pH} 5.0-9.0$. \\
Figure 4C & S. aureus & The lytic activity of LysB4EAD-LysSA11 decreases in the absence of $50 \mathrm{mM} \mathrm{NaCl.}$ \\
Figure 4D & B. cereus & The lytic activity of LysB4EAD-LysSA11 decreases in the absence of $50 \mathrm{mM} \mathrm{NaCl}$. \\
Figure 5A,C & S. aureus & 3.0 $\mu \mathrm{M}$ of LysB4EAD-LysSA11 eliminates all bacterial cells in the boiled rice within $2 \mathrm{~h}$ while \\
& LysSA11 and LyB4EAD in combination $(3.0 \mu \mathrm{M}$ each) eliminates all bacterial cells within $1 \mathrm{~h}$. \\
Figure 5B,D & B. cereus & 3.0 $\mu \mathrm{M}$ of LysB4EAD-LysSA11 eliminates all bacterial cells in the boiled rice within $1 \mathrm{~h}$ while \\
& & LysSA11 and LyB4EAD in combination $(3.0 \mu \mathrm{M}$ each) eliminates 1 log CFU/mL of bacterial cells \\
\end{tabular}

Supplementary Materials: The following are available online at http://www.mdpi.com/2079-6382/9/12/906/s1, Figure S1: The lytic activity of LysSA11, LysB4 and their EADs. Figure S2: The antimicrobial activity of LysSA11 and LysB4 in combination in the boiled rice contaminated simultaneously with S. aureus and B. cereus. Table S1: The decrease in $\mathrm{OD}_{600}$ values of $S$. aureus after addition of endolysins. Table S2: The decrease in $\mathrm{OD}_{600}$ values of $B$. cereus after addition of endolysins.

Author Contributions: B.S. performed the experiments and wrote the paper. B.S., M.K., J.B. and S.R. conceived and designed the experiments. Y.C. participated in experiments. All authors have read and agreed to the published version of the manuscript.

Funding: This research funded by Basic Science Research Programs (2020R1A2B5B03094303) through the National Research Foundation of Korea (NRF) funded by the Ministry of Science, ICT and Future Planning and a grant (20162MFDS142) from Ministry of Food and Drug Safety in 2020. 
Conflicts of Interest: The authors declare no conflict of interest.

\section{References}

1. Scallan, E.; Hoekstra, R.M.; Angulo, F.J.; Tauxe, R.V.; Widdowson, M.A.; Roy, S.L.; Jones, J.L.; Griffin, P.M. Foodborne illness acquired in the United States-Major pathogens. Emerg. Infect. Dis. 2011, 17, 7. [CrossRef] [PubMed]

2. Kumar, T.D.K.; Murali, H.S.; Batra, H.V. Simultaneous detection of pathogenic B. cereus, S. aureus and L. monocytogenes by multiplex PCR. Indian J. Microbiol. 2009, 49, 283-289. [CrossRef] [PubMed]

3. McDowell, R.H.; Sands, E.M.; Friedman, H. Bacillus cereus. In StatPearls; StatPearls Publishing: Treasure Island, FL, USA, 2019.

4. Bennett, S.D.; Walsh, K.A.; Gould, L.H. Foodborne Disease Outbreaks Caused by Bacillus cereus, Clostridium perfringens, and Staphylococcus aureus-United States, 1998-2008. Clin. Infect. Dis. 2013, 57, 425-433. [CrossRef] [PubMed]

5. Fischetti, V.A. Bacteriophage lysins as effective antibacterials. Curr. Opin. Microbiol. 2008, 11, $393-400$. [CrossRef] [PubMed]

6. Loessner, M.J. Bacteriophage endolysins-Current state of research and applications. Curr. Opin. Microbiol. 2005, 8, 480-487. [CrossRef] [PubMed]

7. Schmelcher, M.; Donovan, D.M.; Loessner, M.J. Bacteriophage endolysins as novel antimicrobials. Futur. Microbiol. 2012, 7, 1147-1171. [CrossRef]

8. Fischetti, V.A. Bacteriophage endolysins: A novel anti-infective to control Gram-positive pathogens. Int. J. Med. Microbiol. 2010, 300, 357-362. [CrossRef]

9. Callewaert, L.; Walmagh, M.; Michiels, C.W.; Lavigne, R. Food applications of bacterial cell wall hydrolases. Curr. Opin. Biotechnol. 2011, 22, 164-171. [CrossRef]

10. Kashani, H.H.; Schmelcher, M.; Sabzalipoor, H.; Hosseini, E.S.; Moniri, R. Recombinant endolysins as potential therapeutics against antibiotic-resistant Staphylococcus aureus: Current status of research and novel delivery strategies. Clin. Microbiol. Rev. 2018, 31, e00071-17.

11. Gutiérrez, D.; Fernández, L.; Rodríguez, A.; García, P. Are phage lytic proteins the secret weapon to kill Staphylococcus aureus? mBio 2018, 9, e01923-17. [CrossRef]

12. São-José, C. Engineering of phage-derived lytic enzymes: Improving their potential as antimicrobials. Antibiotics 2018, 7, 29. [CrossRef] [PubMed]

13. Donovan, D.M.; Dong, S.; Garrett, W.; Rousseau, G.M.; Moineau, S.; Pritchard, D.G. Peptidoglycan hydrolase fusions maintain their parental specificities. Appl. Environ. Microbiol. 2006, 72, 2988-2996. [CrossRef] [PubMed]

14. Becker, S.C.; Foster-Frey, J.; Stodola, A.J.; Anacker, D.; Donovan, D.M. Differentially conserved staphylococcal SH3b_5 cell wall binding domains confer increased staphylolytic and streptolytic activity to a streptococcal prophage endolysin domain. Gene 2009, 443, 32-41. [CrossRef] [PubMed]

15. Chang, Y.; Kim, M.; Ryu, S. Characterization of a novel endolysin LysSA11 and its utility as a potent biocontrol agent against Staphylococcus aureus on food and utensils. Food Microbiol. 2017, 68, 112-120. [CrossRef] [PubMed]

16. Son, B.; Yun, J.; Lim, J.-A.; Shin, H.; Heu, S.; Ryu, S. Characterization of LysB4, an endolysin from the Bacillus cereus-infecting bacteriophage B4. BMC Microbiol. 2012, 12, 33. [CrossRef] [PubMed]

17. Low, L.Y.; Yang, C.; Perego, M.; Osterman, A.; Liddington, R.C. Structure and lytic activity of a bacillus anthracis prophage endolysin. J. Biol. Chem. 2005, 280, 35433-35439. [CrossRef] [PubMed]

18. Low, L.Y.; Yang, C.; Perego, M.; Osterman, A.; Liddington, R. The role of net charge on the catalytic domain and the influence of the cell-wall binding domain on the bactericidal activity, specificity and host-range of phage lysins. J. Biol. Chem. 2011, 286, 244160. [CrossRef]

19. Kong, M.; Ryu, S. Bacteriophage PBC1 and its endolysin as an antimicrobial agent against Bacillus cereus. Appl. Environ. Microbiol. 2015, 81, 2274-2283. [CrossRef]

20. Lavigne, R.; Briers, Y.; Hertveldt, K.; Robben, J.; Volckaert, G. Identification and characterization of a highly thermostable bacteriophage lysozyme. Cell. Mol. Life Sci. 2004, 61, 2753-2759. [CrossRef]

21. Chen, X.; Zaro, J.L.; Shen, W.-C. Fusion protein linkers: Property, design and functionality. Adv. Drug Deliv. Rev. 2013, 65, 1357-1369. [CrossRef] 
22. Lu, P.; Feng, M.G. Bifunctional enhancement of a $\beta$-glucanase-xylanase fusion enzyme by optimization of peptide linkers. Appl. Microbiol. Biotechnol. 2008, 79, 579-587. [CrossRef] [PubMed]

23. Zou, G.; Shi, S.; Jiang, Y.; Brink, J.V.D.; De Vries, R.P.; Chen, L.; Zhang, J.; Ma, L.; Wang, C.; Zhou, Z. Construction of a cellulase hyper-expression system in Trichoderma reesei by promoter and enzyme engineering. Microb. Cell Factories 2012, 11, 1-12. [CrossRef] [PubMed]

24. Walkenhorst, W.F.; Klein, J.W.; Vo, P.; Wimley, W.C. The pH dependence of microbe sterilization by cationic antimicrobial peptides: Not just the usual suspects. Antimicrob. Agents Chemother. 2013, 57, 3312-3320. [CrossRef] [PubMed]

25. Leoff, C.; Choudhury, B.; Saile, E.; Quinn, C.P.; Carlson, R.W.; Kannenberg, E.L. Structural elucidation of the nonclassical secondary cell wall polysaccharide from Bacillus cereus ATCC 10987 comparison with the polysaccharides from bacillus anthracis and b. cereus type strain ATCC 14579 reveals both unique and common structural features. J. Biol. Chem. 2008, 283, 29812-29821. [CrossRef] [PubMed]

26. Pillsbury, A.; Chiew, M.; Bates, J.; Sheppeard, V. An outbreak of staphylococcal food poisoning in a commercially catered buffet. Commun. Dis. Intell. 2013, 37, E144-E148.

27. Grande, M.J.; Lucas, R.; Abriouel, H.; Valdivia, E.; Ben Omar, N.; Maqueda, M.; Martínez-Bueno, M.; Martínez-Cañamero, M.; Gálvez, A. Inhibition of toxicogenic Bacillus cereus in rice-based foods by enterocin AS-48. Int. J. Food Microbiol. 2006, 106, 185-194. [CrossRef]

28. Fletcher, S.M.; Boonwaat, L.; Moore, T.; Chavada, R.; Conaty, S. Investigating an outbreak of staphylococcal food poisoning among travellers across two Australian states. West. Pac. Surveill. Response J. 2015, 6, 17-21. [CrossRef]

29. Schmelcher, M.; Loessner, M.J. Bacteriophage endolysins: Applications for food safety. Curr. Opin. Biotechnol. 2016, 37, 76-87. [CrossRef]

30. Arai, R.; Ueda, H.; Kitayama, A.; Kamiya, N.; Nagamune, T. Design of the linkers which effectively separate domains of a bifunctional fusion protein. Protein Eng. 2001, 14, 529-532. [CrossRef]

31. Nelson, M.D.; Fitch, D.H. Overlap extension PCR: An efficient method for transgene construction. In Molecular Methods for Evolutionary Genetics; Springer: Totowa, NJ, USA, 2012; pp. 459-470.

Publisher's Note: MDPI stays neutral with regard to jurisdictional claims in published maps and institutional affiliations.

(C) 2020 by the authors. Licensee MDPI, Basel, Switzerland. This article is an open access article distributed under the terms and conditions of the Creative Commons Attribution (CC BY) license (http://creativecommons.org/licenses/by/4.0/). 